DIGITAL COMMONS
@ UNIVERSITY OF SOUTH FLORIDA

Volume 10

Issue 1 Spring 2020

\section{ABO: Interactive Journal for Women in the Arts, 1640-1830}

2020

\title{
Review of Women's Periodicals and Print Culture in Britain, 1690-1820s: The Long Eighteenth Century
}

\author{
Lisa Maruca \\ Wayne State University, lisa.maruca@wayne.edu
}

Follow this and additional works at: https://digitalcommons.usf.edu/abo

Part of the Dramatic Literature, Criticism and Theory Commons, Educational Methods Commons, Feminist, Gender, and Sexuality Studies Commons, and the Literature in English, British Isles Commons

\footnotetext{
Recommended Citation

Maruca, Lisa (2020) "Review of Women's Periodicals and Print Culture in Britain, 1690-1820s: The Long Eighteenth Century," ABO: Interactive Journal for Women in the Arts, 1640-1830: Vol.10: Iss.1, Article 4. http://doi.org/10.5038/2157-7129.10.1.1231

Available at: https://digitalcommons.usf.edu/abo/vol10/iss1/4
}

This Reviews is brought to you for free and open access by Digital Commons @ University of South Florida. It has been accepted for inclusion in ABO: Interactive Journal for Women in the Arts, 1640-1830 by an authorized administrator of Digital Commons @ University of South Florida. For more information, please contact digitalcommons@usf.edu. 
Review of Women's Periodicals and Print Culture in Britain, 1690-1820s: The Long Eighteenth Century

\author{
Abstract \\ Review of Women's Periodicals and Print Culture in Britain \\ Keywords \\ print culture, periodicals, women, education, authorship, literature \\ Creative Commons License \\ (c) (i) (9)
}

This work is licensed under a Creative Commons Attribution-Noncommercial 4.0 License 
Women's Periodicals and Print Culture in Britain, 1690-1820s: The Long Eighteenth Century. Edited by Jennie Batchelor and Manushag N. Powell. Edinburgh UP, 2018. X+519pp. Index. ISBN: 9781474419659

Reviewed by Lisa Maruca

Wayne State University, USA

It's hard to overestimate the importance of Women's Periodicals and Print Culture in Britain, 1690-1820s: The Long Eighteenth Century, a collection of essays edited by Jennie Batchelor and Manushag N. Powell. The first chronologically in the five-book series, The Edinburgh History of Women's Periodical Culture in Britain, which stretches across more than three hundred years of media history, is simultaneously a key reference work and important collection of new scholarship. As the latter, it breaks new ground, both in its individual essays and the volume as a whole, which is more than just the sum of its parts. Indeed, long overdue, it is, shockingly, the "first sustained treatment of women's print media" (2, my emphasis) in the Eighteenth century, a key era in the periodical's development. An impressive editorial accomplishment by Powell and Batchelor, who ensured that the collection drew on the thinking of both newer and wellestablished scholars, it does nothing less than coalesce a dynamic and emerging area of study, women's periodical culture. This is usefully defined in a broad way, based in the supposition, fully supported across the volume, that "there is no periodical culture in the English tradition without women, full stop" (3). Refuting the notion that women were only passive readers, or worse, merely the imagined construction of texts condescendingly and often insultingly thought appropriate for the them, Batchelor and Powell astutely claim that women permeated all aspects of the creating and reading of periodicals - there is no separate women's sphere. The essays thus cover women's key roles as editors, distributors, literary authors, essay and letter contributors, buyers, readers, and advertisers; at the same time they discuss topics explicitly or implicitly aimed at women readers, debates over women's issues, representations of feminine behavior, and visual imagery of or for women. Taken as a whole, the volume shows that indeed, very few areas of eighteenth-century literary and cultural studies can be understood without reference to women's periodicals, including almost any study of poetry, drama, or the novel, since periodicals by, about, and for women, play such key roles in circulating, reviewing, and framing these works.

In addition to providing a rich collection of individual works, this is a well-organized and resource-rich volume. Divided into six sections, covering education, literature, geographic reach, print culture, theory, and commerce, Women's Periodicals and Print Culture in Britain encompasses over 500 pages by 30 authors. Each section overlaps considerably-these are not so much boxes, as rubrics, since most essays here defy easy categorization. The volume contains 24 illustrations, eight of those color plates - a key addition in a work that draws on visual culture as well as print, though I wish there had been even more, especially focusing on the typographical mise-en-page. A list of Works Cited appears at the end of each essay, a convention that supplies benefits and drawbacks. On the one hand, it highlights the intellectual antecedents of each essay, placing it in its own specific scholarly conversation, but on the other hand, it scatters what could be a useful bibliographical resource into 35 locations in a lengthy volume. A thorough index is helpful for readers wanting to gather information on one topic, author, or work; it also provides a method for identifying the common threads that emerge, or don't. For example, Bluestockings are only mentioned on three pages, while 29 are devoted to consumerism. Another valuable resource is a chronological appendix listing over 100 periodicals that appeared between 1690 and 
1833, though the editors give the caveat that this is neither exhaustive, nor precisely defined. A final example of editorial planning and a sign of the detailed level of scholarship by contributors is number of times these essays refer to each other, creating coherence and stitching together the collection.

With such a long work, it is impossible to discuss any one essay in depth, but themes do emerge. Education is an evergreen topic in the Enlightenment, of course. Eve Tavor Bannet supplies a definitional term, "woman-championing," referring to periodicals written by men that address women as rational beings capable and desirous of expanding their minds, a description so useful that it is brought up many times throughout the collection. Opportunities for women's learning were widespread but heterogeneous. As James Robert Wood makes clear, discussions on the related topics of what constitutes learning and what forms of education were appropriate for women appeared in diverse periodicals across the century. For example, Wood, Nicola Parsons, and Slaney Chadwick Ross address The Ladies' Mercury or The Athenian Mercury, edited by John Dunton, as it stretched the boundaries of propriety by answering questions related to women's sexuality. Later in the century, however, as Hannah Hudson explains, when women authors and actresses were profiled in biographies (a way for women to learn about women), they were represented as chaste and domestic.

Even when not explicitly framing its work as educational, the periodical played a key role in constructing the canon and creating concepts of literary taste. Throughout the volume, familiar authors are seen anew in the context of their periodical publication: Anna K. Sagal and Susan Carlile separately resituate Charlotte Lennox as a feminist with an ambitious agenda for The Lady's Museum; Isobel Grundy explores Lady Mary Wortley Montagu's foray into journalism; Dustin Stewart outlines Elizabeth's Singer fraught textual relationship with John Dunton; and Tanya Marie Caldwell discusses Hannah Cowley's centrality to the Della Cruscan efforts. The mediation of lesser known writers of poetry and fiction, however, is given equal attention, with the complex, interrelated constructions of female authorship and genre teased out in essays by Jennifer Batt, Octavia Cox, and Jenny DiPlacidi. The cultural impact of women editors, often ignored because they don't fit the conventional model of "authoring," is demonstrated in essays by Kathryn R. King (especially enjoyable for its confident, sprightly writing style) and Claire Knowles. Gendered reading and reviewing practices are investigated by Pam Perkins, Rachael Scarborough King, Megan Peiser, and Evan Hayles Gledshill.

The study of periodicals also makes clear that women cannot be relegated to any one sphere. Women are seen participating in political discourse in essays highlighting how periodicals shaped national identity and debates, including those on French Revolution (Koenraad Claes), the early eighteenth-century public sphere (Rachel Carnell), and the economics of war (Catherine Ingrassia). The global eighteenth-century is represented in studies by Alessa John on Germany and JoEllen DeLucia on travel writing. Commodity culture emerges as a key issue, but in ways that debunk stereotypes of superficiality or frivolity: Chloe Wigston Smith takes fashion as a serious pursuit, while Laura Engel shows how celebrity was linked to legitimacy in an increasingly visual culture. Even shopping itself, Serena Dyer explains, was understood as productively patriotic. Of course, advertising is not just about what women buy, but also about what they sell, as Barbara Benedict points out in her investigation of advertisements for female medical practitioners. 
Another important thread woven throughout the volume is the materiality of the periodical, then and now, as Powell and Batchelor call our attention to the connected issues of medium and availability. The digital turn in archiving and (re)presentation has made recovery work possible, allowing projects in both close and distant reading, both of which are included in the volume. Yet, as the editors point out, digitization also raises as many methodological questions as it purportedly answers. First of all, it is incomplete: many periodicals remain scattered and fragmented. Keyword searches rely on unreliable OCR and lead to incomplete results. Screens also obscure the context of a periodical's original mediation, as information on paper quality, size, and illustration quality is lost. In many cases scans were made from bound copies that leave out paratextual elements of the original, including inserts and other features. Yet there are more than technological problems. The project of digitization has not solved the accessibility problem, as subscription databases are expensive, and not available at every institution, much less to independent or precarious scholars at the margins of institutions. Moreover, even when accessible, complete runs can lead to anachronistic reading practices, since eighteenth century readers did not access them this way. Readers did not always read sequentially, but dipped in and out of individual issues, read them as excerpts in miscellanies, or saw them as reissues or bound in volumes. This makes a difference in how their contents was imbibed. As Bannet points out, “readers' discontinuous reading of miscellaneous fragments. . scattered the unified ideological message, and dissipated the inescapably regulatory impact attributed to them by modern analyses. .." (49).

No volume, regardless of scope, can cover it all. Despite the emphasis on mediation, for example, there is more remaining to be said about materiality, economics, and those who worked in the print trade. The title of the section, "Print Media and Print Culture," suffers from the fact that the term "print culture" has become somewhat of a cipher in recent years; the vagueness of the term frustrates more than it elucidates. There are notable exceptions. Claes brings in the radical politics of bookseller George Robinson, the publisher of The Lady's Magazine. Cox investigates the editor James Harrison, of the Harrison family publishing house, using both quantitative and spatial analyses to measure his commitment to women writers. Knowles dissects the differing financial motivations in the publishing partnership that started The World. There are also disappointments as well: King gives tantalizingly few details on Brooke's relationship with renowned bookseller Andrew Millar. Clearly, more research is needed on how women interacted with the print trade and reciprocally, how the print trade supported and materially profited from these endeavors by or about women. There are other gaps. Nothing emerges on queer sexualities, and little on how the periodical may have participated in the imperialist projects of the era. It may seem churlish to point to these shortcomings when the volume does so much. Yet these are not as much drawbacks as points remaining to be explored in what the editors and authors have shown is - indeed, have created - a rich and diverse field. That I am left wanting even more only shows how well they have done their job. 